\title{
O MAL-ESTAR DO ENSINO RELIGIOSO NAS ESCOLAS PÚBLICAS
}

\author{
ANA MARIA CAVALIERE \\ Faculdade de Educação da Universidade Federal do Rio de Janeiro \\ anamariacavaliere@fe.ufrj.br
}

\begin{abstract}
RESUMO
O artigo apresenta os resultados de uma pesquisa realizada em I 4 escolas da rede estadual do Rio de Janeiro, onde se analisou o processo de implementação do ensino religioso confessional como disciplina regular. Os depoimentos de 96 professores demonstraram que ainda que predomine o apoio à disciplina, há um mal-estar nas escolas quanto ao seu caráter confessional. O estudo mostrou também que a expectativa de reforço do controle social foi a base para a aceitação da disciplina pelos professores. EDUCAÇÃO RELIGIOSA - ESCOLAS PÚBLICAS - RIO DE JANEIRO
\end{abstract}

\begin{abstract}
UNEASINESS OVER RELIGIOUSEDUCATION IN PUBLIC SCHOOLS. The article presents the findings of a research conducted in 14 state public schools in Rio de Janeiro, aiming to analyze the process of implementing confessional Religious Education as a regular discipline. The testimony of 96 teachers shows that, despite the support granted to the discipline, its confessional nature causes uneasiness in the schools. The study shows also that teachers' acceptance of the discipline was based on the expectation of social control reinforcement. RELIGIOUS EDUCATION - PUBLIC SCHOOL - RIO DE JANEIRO
\end{abstract}


O ensino religioso apresenta-se hoje como uma questão para a educação brasileira, se não propriamente nova, renovada em suas determinações. Num momento em que as religiões crescentemente ocupam maiores e mais importantes espaços sociais e políticos, a ratificação legal ocorrida recentemente em diversos níveis da legislação do país, e, dentro dela, a regulamentação do financiamento público do ensino religioso representam mudança significativa nas relações entre as esferas pública e privada e também na concepção de Estado laico. A situação que hoje vive o Rio de Janeiro é reveladora das múltiplas contradições que a questão introduz no sistema educacional público, seja no âmbito das relações institucionais, seja na prática cotidiana escolar.

Em setembro de 2000, a Assembléia Legislativa do Estado do Rio de Janeiro promulgou a Lei n.3.459 que instituiu o ensino religioso confessional nas escolas públicas do estado. Com ela, a obrigatoriedade de oferta do ensino religioso na rede estadual se estendeu a toda a educação básica, à educação profissional e à educação especial, não se restringindo, conforme estabelece a Lei de Diretrizes e Bases da Educação Nacional - LDB -, ao ensino fundamental. Ainda de acordo com a lei, o conteúdo desse ensino tornou-se "atribuição específica das diversas autoridades religiosas, cabendo ao Estado o dever de apoiá-lo integralmente". Quanto aos professores, poderão ministrar aulas de ensino religioso se e enquanto forem credenciados pela autoridade religiosa do credo a que se propõem lecionar. Devem ingressar no quadro permanente do magistério público estadual ou, quando necessário, podem ser contratados por tempo determinado. Do ponto de vista do alunado, o ensino religioso é facultativo, sendo a escolha do credo feita pelos pais ou responsáveis no caso de alunos até 16 anos, e pelos próprios alunos, a partir dessa idade. $\bigcirc$ artigo $1^{\circ}$ da lei traz a afirmação de que são "vedadas quaisquer formas de proselitismo".

O debate travado na Assembléia Legislativa Fluminense, no processo de promulgação da lei, separou de um lado os que defendiam o ensino religioso interconfessional e, de outro, os que o defendiam na forma confessional (Giumbelli, Carneiro, 2004). O fato de a LDB fornecer garantia para a oferta regular dessa matéria desestimulou a formação de um bloco político que atuasse contra a inclusão do ensino religioso nas escolas. Quanto à população do estado, esta esteve distante e desinformada, não chegando a participar do debate. A repercussão das discussões parlamentares foi pequena e fragmentada na imprensa e praticamente nula nas esferas acadêmicas do estado. 
O mal-estar do ensino religioso..

Com base na Lei n.3.459, foram criadas por decreto 500 vagas para professores de religião, distribuídas, de acordo com estudo estatístico, feito pela Secretaria de Educação, da seguinte forma: 342 vagas para católicos, 132 vagas para evangélicos e 26 vagas para outros credos. Para concorrer a uma vaga, o candidato ao magistério dessa disciplina deveria "possuir curso de formação universitária com licenciatura" plena em qualquer disciplina e ser credenciado pela autoridade religiosa do respectivo credo. Em janeiro de 2004 foi realizado o concurso público e, a partir de abril daquele mesmo ano, a maior parte dos aprovados para as 500 vagas já se encontrava em atividade nas escolas.

O empenho do Governo do Estado do Rio de Janeiro, para a implantação do ensino religioso nas escolas, nos períodos 1999-2002 e 2003-2006, torna-se evidente quando se leva em conta que à época da contratação dos novos professores dessa matéria, professores de outras disciplinas, aprovados em concursos anteriores, aguardavam ser chamados.

A contestação à modalidade de ensino religioso implantada no Estado do Rio de Janeiro veio da Confederação Nacional dos Trabalhadores em Educação que, em 2004, argüiu a inconstitucionalidade da Lei n. 3.459 considerando que esta, mesmo baseada na LDB, a extrapola quando estende o ensino religioso a todos os níveis da educação básica e quando possibilita que uma entidade religiosa, estranha ao poder público, interfira na carreira profissional de servidores públicos, o que trairia o espírito de independência entre estado e credo religioso.

Para além das disputas políticas e legais, a presença do ensino religioso nas escolas da rede estadual do Rio de Janeiro já constitui uma realidade instalada, a ser conhecida e analisada.

O trabalho que se segue está baseado em um estudo exploratório que observou e registrou, em 14 escolas da rede estadual, as soluções organizacionais e didático-pedagógicas por elas encontradas para a viabilização das aulas de ensino religioso. Registrou-se a opinião dos diferentes profissionais docentes sobre essa disciplina e as relações estabelecidas entre as instituições religiosas credenciadoras e os professores específicos da matéria.

Neste texto, apresentam-se as formas organizacionais e pedagógicas do ensino religioso observadas nas escolas da amostra, a repercussão no conjunto da vida escolar da presença do ensino religioso como disciplina formal e a opinião de diretores e professores a respeito das funções que esse ensino pode assumir na formação dos alunos. 
O fortalecimento das práticas religiosas nas sociedades contemporâneas, no qual se insere a temática deste artigo, é um fenômeno complexo e que revela concepções de mundo em disputa. Se a implantação do ensino religioso nas escolas é indício da chamada dessecularização - fenômeno típico do fim de século - a análise de sua implantação concreta revela as contradições de uma disputa cultural e política. $\bigcirc$ contundente processo de secularização da cultura pelo qual passou a civilização ocidental ao longo de todo o século $X X$ se mostra em cada detalhe da prática do ensino religioso nas escolas do Rio de Janeiro, e nas dificuldades que a acompanham. A própria concepção de religião (ou de compromisso religioso) parece assumir novos contornos: os contornos possíveis no mundo da impessoalidade, da individualização e do consumo.

\section{AS ESCOLAS ESTUDADAS}

O estudo' foi realizado entre maio de 2005 e maio de 2006. Das 14 escolas estudadas, como se pode ver no quadro I, seis estão localizadas na capital e oito na região da Baixada Fluminense. $O$ critério de seleção de escolas para a composição da amostra teve por base a conjugação da presença do ensino religioso na unidade escolar com a variedade dos níveis de ensino existentes na rede estadual. Assim, fazem parte da amostra desde escolas com todos os níveis de ensino até escolas com apenas o ensino médio, conforme assinalado com $X$ no quadro I. Já os níveis de ensino efetivamente contemplados com o ensino religioso em cada escola da amostra estão assinalados pela abreviatura ER, com a qual passaremos a designar a disciplina neste artigo.

A maior dentre as escolas estudadas tem 3.160 alunos e abrange todos os segmentos da educação básica, com exceção do ensino técnico. A menor tem 780 alunos, todos do ensino médio regular noturno. Ainda que esteja citado na lei estadual, o ER não foi incluído na grade horária das modalidades de Ensino Técnico e Normal. Já nos segmentos de educação infantil e de $1^{a}$ a $4^{\mathrm{a}}$ série, há raras ocorrências. Por orientação da Secretaria Estadual de Educação, a maior

I. Participaram da equipe de pesquisa Eunice Maria Ferreira Silva, Jordanna Castelo Branco, Juliana Lopes e Vanessa Lima. 
O mal-estar do ensino religioso...

parte da oferta de ER concentra-se da $5^{\mathrm{a}}$ a $8^{\mathrm{a}}$ série e no ensino médio regular, que tiveram essa disciplina incorporada à grade horária oficial a partir de 2004.

Nas 14 escolas da amostra foram entrevistados, ao todo, 16 professores de ER. Foram entrevistados também 20 profissionais componentes das equipes de direção dessas escolas, entre eles oito diretores gerais, dez direto-

QUADRO I

OFERTA E DISTRIBUIÇÃO DO ER POR NIVEEIS DE ENSINO

\begin{tabular}{|c|c|c|c|c|c|c|}
\hline NÍVEL & Ed. Infantil & $1^{a} / 4^{a}$ & $5^{a} / 8^{a}$ & E. Médio & Normal & Técnico \\
\hline Escola I & & & X & $x$ & & \\
\hline Nilópolis & & & ER & ER & & \\
\hline Escola 2 & & & $x$ & $x$ & & $x$ \\
\hline Nilópolis & & & ER & ER & & \\
\hline Escola 3 & & $x$ & $x$ & $x$ & $x$ & \\
\hline N.lguaçu & & & ER & ER & & \\
\hline Escola 4 & & & X & $x$ & & \\
\hline N.lguaçu & & & ER & ER & & \\
\hline Escola 5 & $x$ & $x$ & & $x$ & $x$ & \\
\hline Japeri & ER & ER & & & & \\
\hline Escola 6 & & & $x$ & $x$ & & \\
\hline N.lguaçu & & & ER & ER & & \\
\hline Escola 7 & $x$ & $x$ & $x$ & $x$ & $x$ & \\
\hline D. Caxias & & & ER & & & \\
\hline Escola 8 & & & $x$ & $x$ & & \\
\hline D. Caxias & & & ER & ER & & \\
\hline Escola 9 & & & & $x$ & & $x$ \\
\hline Rio de Janeiro & & & & ER & & \\
\hline Escola 10 & & & & $x$ & & \\
\hline Rio de Janeiro & & & & ER & & \\
\hline Escola |I & & & & $x$ & & \\
\hline Rio de Janeiro & & & & ER & & \\
\hline Escola 12 & & & & $x$ & & \\
\hline Rio de Janeiro & & & & ER & & \\
\hline Escola 13 & & & & $x$ & & $x$ \\
\hline Rio de Janeiro & & & & ER & & \\
\hline Escola 14 & & & & $x$ & & \\
\hline Rio de Janeiro & & & & ER & & \\
\hline
\end{tabular}

Fonte: Amostra de 14 escolas da rede estadual do Rio de Janeiro. 
QUADRO 2

PROFESSORES ENTREVISTADOS POR ESCOLA E FUNÇÃO

\begin{tabular}{|c|c|c|c|c|}
\hline ESCOLA & $\begin{array}{l}\text { Membros } \\
\text { da direção }\end{array}$ & \begin{tabular}{|c|} 
Professores de \\
outras disciplinas
\end{tabular} & $\begin{array}{c}\text { Professores } \\
\text { de ER }\end{array}$ & Total \\
\hline $\begin{array}{l}\text { Escola I } \\
\text { Nilópolis }\end{array}$ & 2 & 3 & । & 6 \\
\hline $\begin{array}{l}\text { Escola } 2 \\
\text { Nilópolis }\end{array}$ & 3 & 3 & 2 & 8 \\
\hline $\begin{array}{l}\text { Escola } 3 \\
\text { N.lguaçu }\end{array}$ & 3 & 4 & । & 8 \\
\hline $\begin{array}{l}\text { Escola } 4 \\
\text { N.lguaçu }\end{array}$ & I & 8 & I & 10 \\
\hline $\begin{array}{l}\text { Escola } 5 \\
\text { Japeri }\end{array}$ & I & 5 & I & 7 \\
\hline $\begin{array}{l}\text { Escola } 6 \\
\text { N.Iguaçu }\end{array}$ & I & 4 & I & 6 \\
\hline $\begin{array}{l}\text { Escola } 7 \\
\text { D. Caxias }\end{array}$ & । & 4 & । & 6 \\
\hline $\begin{array}{l}\text { Escola } 8 \\
\text { D.Caxias }\end{array}$ & I & 4 & I & 6 \\
\hline $\begin{array}{l}\text { Escola } 9 \\
\text { Rio de Janeiro }\end{array}$ & 2 & 3 & । & 6 \\
\hline $\begin{array}{l}\text { Escola } 10 \\
\text { Rio de Janeiro }\end{array}$ & I & 5 & I & 7 \\
\hline $\begin{array}{l}\text { Escola I I } \\
\text { Rio de Janeiro }\end{array}$ & । & 7 & । & 9 \\
\hline $\begin{array}{l}\text { Escola } 12 \\
\text { Rio de Janeiro }\end{array}$ & I & 2 & I & 4 \\
\hline $\begin{array}{l}\text { Escola } 13 \\
\text { Rio de Janeiro }\end{array}$ & । & 3 & 2 & 6 \\
\hline $\begin{array}{l}\text { Escola |4 } \\
\text { Rio de Janeiro }\end{array}$ & I & 5 & । & 7 \\
\hline TOTAL & 20 & 60 & 16 & 96 \\
\hline
\end{tabular}

Fonte: Amostra de 14 escolas da rede estadual do Rio de Janeiro.

res adjuntos e dois coordenadores pedagógicos. Quanto às demais disciplinas, 60 professores responderam a um questionário padronizado, a partir do qual, na maior parte das vezes, seguiram-se entrevistas complementares. No conjunto, foram colhidas opiniões de 96 profissionais docentes. 
O mal-estar do ensino religioso..

\section{A RECEPTIVIDADE DAS ESCOLAS AO ER}

De acordo com as declarações obtidas, foi problemática, nas escolas, a receptividade ao ER e seus respectivos professores. Em todas as unidades escolares estudadas houve estranhamento entre esses professores e o restante do corpo docente, como se percebe nos depoimentos a seguir:

Sei que muitos professores não valorizam o trabalho de ER, mas eu me relaciono bem com todos; eles não chegam a falar mal da minha disciplina na minha cara, mas fazem comentários que não deviam com os próprios alunos; como por exemplo: "para que essa disciplina na escola?" "O ER não reprova e não pode ser obrigatório", e outras coisas mais. Os alunos vêm confirmar estes comentários. (Professor 4 de ER )

Tanto aqui quanto lá na outra escola tem sido boa; eu sinto que a receptividade é boa; mas tem alguns professores que dizem: "eu não gosto dessa matéria", mas eu respeito. Aqui tem professor que não aceita, você vê esse que saiu? [um professor fez cara de desaprovação e se retirou da sala]. A rejeição é só de alguns professores. De um modo geral os professores de física, matemática se acham melhores; mas digo pra eles que não fomos nós que decidimos que a escola teria que ter religião, e aí a gente tem que cumprir. (Professor 8 de ER)

É bem verdade que preconceito existe em qualquer lugar... Eu acho que inicialmente traçaram um estereótipo de que ensino religioso é aquele mito que eu já disse, e me olhavam como se eu fosse um ET, inclusive falaram algumas coisas de início que eu não gostei, mas... superei. $\bigcirc$ superar é mostrar para eles que não é nada daquilo que eles estavam pensando e com o passar do tempo eu fui ganhando um pouco de credibilidade. (Professor 5 de ER)

Esse desconforto esteve relacionado, entre outras coisas, ao problema da falta de professores na rede estadual do Rio de Janeiro, que é crônico e arrasta-se ao longo dos anos. Apesar de um grande rearranjo feito em 2004, visando melhor distribuir os professores pelas escolas, o problema permanece grave. No início de 2006, a Secretaria Estadual de Educação - SEE - ofereceu 10 mil vagas para contratação de professores temporários, pelo período 
de dois anos, em diversas disciplinas ${ }^{2}$. $\bigcirc$ ER também foi contemplado com vagas para professores temporários.

$\mathrm{Na}$ falta de outra justificativa, parece ter sido a pequena quantidade de professores o que levou a SEE, na citada reorganização de 2004, a diminuir o número de aulas de História e Ciências, no segmento de $5^{\mathrm{a}}$ a $8^{\mathrm{a}}$ série, de quatro para três horas-aula semanais. Essa diminuição ocorreu no mesmo momento em que se inseria na grade horária não apenas da $5^{a}$ a $8^{a}$ série, mas também do ensino médio ${ }^{3}$ uma aula semanal de $E R$, já com os professores recém-concursados. A coincidência desses fatos incomodou boa parte do professorado que, inicialmente, não recebeu bem a nova disciplina e o novo professor. Na grande maioria das escolas, entretanto, essa inclusão do ER na grade horária significou, na prática, um tempo vago compulsório para as turmas de $5^{a}$ a $8^{a}$ série e de ensino médio, já que os cerca de 500 professores contratados nem de longe puderam suprir a necessidade criada.

... eu não tenho certeza para te dizer, mas esses tempos de ensino religioso, eu não tenho muita informação, mas parece que foram retirados de outras disciplinas. Então eu acho que eles diminuíram a carga horária, por exemplo, de história, biologia, para que o governo tivesse condição de pagar o pessoal do ensino religioso, isso está tudo errado. Então, a resistência no início do ano passado foi muito grande. Quer dizer, eu já me deparei com uma realidade complicada, com colegas que chegavam perto da gente com aquela, afrontando, e aí a gente tem que se colocar, se posicionar: "eu sou concursada como você, eu batalhei uma vaga como você, eu tenho formação como você"; porque todos os professores do ensino religioso têm que ter uma segunda formação. Então, puxa! E aí a gente foi conquistando aos poucos o nosso espaço. Mas hoje eu posso dizer para você que eu, sem demagogia, me sinto realizada no que eu estou fazendo aqui dentro. Porque eu sou reconhecida, primeiro pelos meus alunos e, segundo, pelos meus colegas de trabalho. (Professor I de ER)

2. A rede estadual do Rio de Janeiro é composta por I.854 unidades escolares onde trabalham 77 mil professores.

3. A grade horária de cada turma da rede estadual está disponível em http://www.see.rj.gov.br. 
O mal-estar do ensino religioso...

problema da falta de professores em diversas disciplinas gerou situações bizarras como a presenciada em uma das escolas estudadas: a falta de professor de química deixara várias turmas sem essa matéria durante todo o ano de 2005. Em contrapartida, a professora de ER era licenciada em química, atuando nessa disciplina em outra unidade escolar da rede estadual, com sua outra matrícula.

Em 8 das 14 escolas visitadas fomos informados de que havia falta de professor para uma ou mais disciplinas de $5^{a}$ a $8^{a}$ e do ensino médio, e entre os 16 professores de ER entrevistados, encontramos três deles que já haviam sido aprovados em concursos anteriores, para suas disciplinas de origem, mas que não chegaram a ser contratados.

No decorrer dos anos de 2004 e 2005, as resistências internas aos professores de ER tenderam a ser aplacadas, diluídas pelo espírito de corpo, que sempre termina por se impor no cotidiano das instituições públicas. Ressaltese que o sistema estadual do Rio de Janeiro admite que um mesmo professor acumule duas matrículas de 16 ou 20 horas. Sendo assim, diversos professores que já pertenciam aos quadros da rede estadual prestaram concurso para adquirir a segunda matrícula com a disciplina ER. Entre os 16 professores de ER que entrevistamos, sete deles já possuíam matrícula em outra disciplina. Nesses casos, o "reconhecimento" pelos colegas dos novos integrantes da categoria foi facilitado. Além disso, o mesmo elemento inicialmente causador de resistências - a falta crônica de pessoal - acabou por atuar na linha de uma adaptação/incorporação desse professor. Em muitos casos os professores de ER estão trabalhando em atividades relacionadas à orientação educacional, área hoje esvaziada de profissionais nas redes públicas, ou em trabalhos considerados do âmbito dos temas transversais ${ }^{4}$, ou ainda em atividades extraordinárias, de cunho cultural e festivo.

...elas foram me chamar: "Você está no tempo vago?" E eu respondi: "Estou". "Será que você não pode fazer...", e eu perguntei “ - É pepino?”. É pai de aluno,

4. Os temas transversais integram os Parâmetros Curriculares Nacionais do Ensino Fundamental e devem estar presentes nas disciplinas convencionais. São eles: ética, saúde, meio ambiente, orientação sexual, trabalho e consumo, pluralidade cultural e temas locais. 
aluno, tudo eles mandam me chamar. Eles falam: "vem conversar com essa mãe que saiu de casa, que não sei o quê, que o menino brigou”, então tudo é a professora de religião. Então que Deus seja glorificado nisso, que pelo menos agora a gente não está sendo visto como um entrave na escola. Não, a gente vem para somar, para ajudar. (Professor I de ER)

Em resumo, a resistência inicial aos professores de ER deveu-se em parte às disputas internas à categoria docente por espaços no currículo e na grade horária e também a um mal-estar efetivo com a presença institucionalizada da religião no espaço escolar. Entretanto, com o passar do tempo, a solidariedade profissional, a necessidade de mais professores e a expectativa de que esses novos professores passem a exercer funções subsidiárias ao equilíbrio da vida escolar cotidiana têm levado os profissionais docentes a uma aceitação paulatina.

\section{RELIGIÃO E CONTROLE SOCIAL: A FOCALIZAÇÃO NOS ADOLESCENTES}

A concentração da oferta do ER na $5^{\mathrm{a}}$ a $8^{\mathrm{a}}$ séries e no ensino médio regular recebeu muito mais apoios do que críticas do conjunto de profissionais entrevistados. Apenas uma professora de ER e duas diretoras de escola - essas últimas defensoras do ER - manifestaram a opinião de que este ensino deveria estar voltado para as crianças pequenas, de modo, segundo elas, a deixar uma marca efetiva em sua formação. Outra professora de ER manifestou a opinião de que o curso normal é que deveria ser contemplado prioritariamente, alegando a importância desse tipo de formação para o futuro professor, ou seja, na formação dos formadores, revelando assim uma preocupação com a reprodução e permanência da religião na vida escolar.

$O$ fato do ER nas escolas dirigir-se, no Rio de Janeiro, especialmente aos adolescentes e jovens parece estar relacionado ao próprio significado que a religião tem assumido na vida contemporânea. Analisando os dados coletados, viu-se que, freqüentemente, e de forma quase padronizada, professores e diretores se referiam aos alunos como estando "desorientados", "sem valores" e "sem referências". Profissionais docentes, aparentemente muito diferentes entre si - a começar pela diferença de serem ou não professores de ER -, 
repetiam o diagnóstico sobre os alunos, que poderia ser aqui sintetizado como falta de integração social e de referência a valores morais. Os depoimentos de professores e diretores sobre as dificuldades de lidar com os "jovens de hoje", sobre as atitudes que consideram desrespeitosas dos alunos para com eles, bem como sobre a agressividade entre eles próprios, repetiram-se ad nausea.

$\bigcirc$ argumento mais freqüentemente utilizado por aqueles professores que justificavam ou defendiam a presença do ER nas escolas baseava-se na idéia de que ele poderia atuar como força integradora para "essa geração quase perdida".

Tudo isso favorece a interpretação de que o ER está sendo visto pelos profissionais da educação como recurso para enfrentar os problemas de violência, indisciplina e conflitos na escola, ou seja, como solução emergencial para o clima de desagregação dos princípios de solidariedade e convivência social que é fortemente sentido nas instituições escolares. Embora as 14 escolas que compõem essa amostra não sejam particularmente atingidas pela violência, uma vez que nenhuma delas se encontra no interior de comunidades conflagradas, ainda assim sofrem os efeitos da disseminação da cultura da "violência difusa" (Santos, 2004). A dificuldade dos professores de lidar com alunos desinteressados, rebeldes ou transgressores, e a sensação de perda de autoridade têm sido grande e generalizada. Assim, as aulas de religião, na prática, passaram a ser justificadas, por muitos professores, como uma ferramenta a mais nessa luta pelo fortalecimento do controle social e conseqüente preservação da autoridade.

Se a formação religiosa estivesse sendo entendida como uma responsabilidade inerente, ou imprescindível à formação escolar, provavelmente a defesa de sua inserção nos segmentos mais precoces da escolarização teria aparecido com mais freqüência nos depoimentos.

A ineficiência do controle social exercido pelas instituições societárias tais como a família, as associações comunitárias e a própria escola por meio de suas funções típicas, parece levar a um raciocínio compensatório em relação à possibilidade de a religião exercer de forma mais efetiva esse papel. A percepção generalizada de que há uma predisposição, entre muitas famílias de alunos, de adesão a um credo religioso, faz parecer profícuo esse caminho, inclusive para alguns professores e diretores que não estão pessoalmente envolvidos na prática de alguma religião.

O sentido moralizador da religião é aludido pelos professores que, no entanto, sempre fazem questão de declarar sua neutralidade quanto aos dife- 
rentes credos, isto é, fazem questão de afirmar que todos eles poderiam igualmente cumprir esse papel. Será visto adiante como as religiões afro-brasileiras, no entanto, ficaram fora desse raciocínio que comportava apenas as religiões cristãs.

O depoimento a seguir é representativo daqueles professores de ER que estão fortemente imbuídos da convicção de que poderão modificar comportamentos e perspectivas de seus alunos mediante sua ação:

...quando eu vou ao conselho de classe eu opino sobre a conduta deles. Eu pergunto até a elas [professoras]: "Mudaram de conduta?", e elas me contam, que às vezes eles [alunos] lembram: "Você viu que a tia disse que não pode bater? Deus tá te vendo, hein? Deus tá vendo tudo! Tá vendo que você não pode roubar, não pode tirar o lápis do outro."

...um aluno me disse: "Eu não gosto, eu não gosto da senhora, de certa forma". E eu perguntei pra ele por que, e ele disse: "Eu vou ser que nem o meu irmão, bêbado de cair". Aí, eu falei: "Ah, não... Deus não tem esse plano pra sua vida! Você não precisa ser assim..." Aí, eu sentei com ele, conversei com ele, até falei na reunião de pais sobre isso, mas nem sei se os pais dele vieram ou não. Eu falei pra ele: "Deus quer te dar um emprego legal, que você estude, bote dinheiro no bolso. Ele vai ajudar você, vai ter tudo pra você comprar, pra comer..." Fiz aquele teatro, e o garoto agora participa bem da aula, presta atenção, faz as coisas, eu senti que ele tomou um novo rumo. (Professor 2 de ER)

\section{O CARÁTER CONFESSIONAL E FACULTATIVO}

A descrição contida na Lei n.3.459 é clara quanto ao caráter confessional do ensino religioso. Entretanto, a falta de infra-estrutura que propicie a sua efetivação, ao lado da reelaboração de significados feita pelos profissionais da educação relativa aos objetivos dessa disciplina, tem levado a uma prática muito distante do estipulado pela lei.

Em nenhuma das escolas da amostra se faz a separação dos alunos de acordo com sua religião. $\bigcirc$ número pequeno de professores por escola, muitas vezes de um só credo, as dificuldades de reorganizar as turmas dentro do 
O mal-estar do ensino religioso...

horário regular e a opinião dos professores sobre a inadequação do ER confessional no espaço escolar, impedem a prática desse tipo de ensino.

Outro empecilho à separação em grupos é a inexistência de atividades alternativas para os alunos que não tenham professor disponível de seu credo ou que não queiram assistir às aulas de ER. Em nenhuma das escolas estudadas existe esse tipo de oferta. Os que não assistem às aulas de religião ficam ociosos. Esse fato tem implicações graves no que tange ao direito de escolha dos alunos e suas famílias: muitos diretores justificaram o fato de não esclarecem seus alunos sobre a não-obrigatoriedade das aulas de religião por falta de alternativas a lhes oferecer, o que traria problemas organizacionais e disciplinares. Em geral, os estudantes de ensino médio adquirem essa informação por si próprios, mas os de $5^{\mathrm{a}}$ a $8^{\mathrm{a}}$ série ainda não possuem autonomia para tal e, com freqüência, são mantidos intencionalmente na condição da dúvida e, como conseqüência, na obrigatoriedade de fato. Um esclarecimento inequívoco sobre o caráter opcional das aulas de ER levaria a que muitos alunos passassem a não assisti-lo.

Os depoimentos dos alunos sobre como eles são informados acerca da não-obrigatoriedade e também de que a matéria não reprova chamam a atenção para a difícil situação em que se encontram os diretores e professores de ER, empurrados para uma posição eticamente questionável.

Eu procuro não deixar isso claro. Porque eu não falo que sim, também não falo que não. Eu mando eles procurarem na direção [...] porque à medida que eu tenho que trabalhar com verdade, eu não posso mentir... eu prefiro não mentir, mas omitir. Essa é a grande questão. (Professor 5 de ER)

Porque no edital [do concurso] dizia que o ensino seria opcional, do que eu conclui: "será fora de aula". Achei que eu ia entrar numa sala de aula e eu falaria pro garoto: "é opcional, você assiste se você quiser". Só que na realidade isso não vem sendo assim, desde o ano passado, tornou-se obrigatório. Ele até pode sair, ter livre acesso, mas será que se os 40 quiserem sair, será que vão sair, entende? Eu digo para ele que pode ficar lá fora e, é claro, que se ele falar: "professor eu tô a fim de ficar lá fora"... eu digo "Vai lá meu jovem tá tudo bem; só assuma quando a diretora te pegar que é opção sua ficar e não que eu coloquei para fora". Caso eu coloque, aí eu vou assumir. (Professor 3 de ER) 
Pela lei é facultativo. Seria o pai, se ele fosse menor de 16 anos; é o pai que responde por ele. Depois ele que responde, só que isso nós não divulgamos. Então, o aluno tem que ficar ali, pois se a gente divulga, o que a direção vai fazer com os alunos que não querem? Vai ter que dar uma atividade pra eles. Nós não temos espaço nem profissionais para cuidar disso, então eu procuro mantê-los na sala de aula envolvidos com atividades ou, então, deixo ele quietinho no canto. (Professor 6 de ER)

...e eu retruco dizendo: "se não reprova, porque eu preparei todo este material de apostila para trabalhar com vocês? Por que eu anoto todos os trabalhos de vocês? Por que eu dou nota e cobro a presença?" E assim vou levando e mantendo a turma cheia. (Professor 4 de ER)

Em todas as escolas estudadas, a busca por informações relativas a como os alunos têm conhecimento do caráter optativo do ER obteve respostas evasivas ou contraditórias. Às vezes a direção diz que informa essa condição, mas o professor de ER diz que evita passar a informação. Outras vezes dá-se o contrário. Fica claro que o caráter optativo, dentro da grade horária obrigatória, é um problema de difícil trato para a organização da vida escolar e para o professor de ER.

Poucos casos foram relatados de responsáveis que procuram a escola e proíbem que seus filhos menores de 16 anos freqüentem o ER, ou seja, o movimento se inverteu: pela lei o responsável deve autorizar que o aluno freqüente o ER, na prática, ele precisa tomar a iniciativa de desautorizar.

No caso do ensino médio noturno, a presença de alunos é muito pequena. Muitas vezes o horário do ER está localizado no início ou no fim do turno, o que torna a freqüência ainda mais rara.

As informações colhidas e as observações feitas permitem a conclusão de que a efetividade do ER nas turmas de ensino médio tem sido pequena. Particularmente nas turmas noturnas, a presença é baixíssima, e os professores sentem-se desmoralizados e desmotivados. É com os alunos de $5^{\mathrm{a}}$ a $8^{\mathrm{a}}$, que eles têm tido uma ação mais regular e efetiva, justamente pela obrigatoriedade de freqüência que ocorre na prática.

.... aluno que é do ensino médio à noite, ele vem do trabalho pra conseguir estudar e aprofundar naquelas matérias, para ter o diploma no final do ano. Ele 
O mal-estar do ensino religioso...

não está aqui como o de $5^{\mathrm{a}}$ a $8^{\mathrm{a}}$ que sente necessidade de passar por todas as disciplinas que recebe nesse horário da manhã. $\bigcirc$ da noite não! Ele já vem cansado do trabalho tudo isso tem que ser pesado; mas eu não chego a dizer se é obrigado ou não; porque se eu disser que não é [obrigado] a aula vai ficar vazia. (Professor 10 de ER)

A intenção era ter um professor de cada religião e os alunos separados por credo, mas já se sabe que a igreja já passa o ensino religioso; acho que a coisa fica repetitiva, pois estuda aqui na escola e na igreja também, aí o aluno não quer ficar na aula; por isso é que essa aula não funciona na prática. (Professor 7 de ER)

Quanto ao caráter confessional previsto em lei, ainda que os 12 professores entrevistados afirmem não trabalhar dessa forma a orientação oficial que têm recebido, coordenada e liderada pela Igreja Católica, tem esse caráter. A centralização e maior força organizativa da Igreja Católica leva a que a maior parte das ações de treinamento dos professores seja feita sob sua liderança. Em muitos casos, os encontros são conjuntos, com professores de todos os credos, em dependências da Igreja Católica, sempre com o objetivo de reforçar o trabalho confessional. $\bigcirc$ trecho que se segue foi extraído de texto apresentado pela Coordenadora de Educação Religiosa da Secretaria Estadual de Educação, num encontro para professores de ER da rede estadual, realizado em outubro de 2005, em conjunto com o Conselho Episcopal Regional Leste I da Conferência Nacional dos Bispos do Brasil - CNBB.

A contrário do que muitos dizem, o objeto do Ensino Religioso não é o Ecumenismo ou o Diálogo Inter-religioso, nem mesmo a Ética e os Valores. Se assim fosse, não se justificaria o Ensino Religioso como disciplina, pois outras, tais como Filosofia, a Sociologia dariam conta desses conteúdos de maneira muito mais eficaz e, provavelmente, de maneira mais interessante. Também não se trata da História das Religiões, isso a História pode fazer melhor do que qualquer professor de religião. Outra coisa que precisa ficar clara é que não existe neutralidade, imparcialidade em educação. Qualquer que seja a disciplina, o professor é uma pessoa marcada culturalmente, forjada pelo tempo e por seu contexto histórico-social, haja vista as aulas de História que, em sua maioria revelam a formação histórico-marxista de nossos colegas. Portanto o professor ensina, não ape- 
nas segundo o conhecimento que carrega sobre o assunto em questão, mas tem uma visão de mundo, uma postura crítica, ou seja, o professor carrega consigo um juízo sobre a realidade. A grande questão é como se forma esse juízo. A experiência religiosa, certamente, influencia a visão de mundo. Um católico não estabelece um juízo sobre as circunstâncias partindo dos mesmos critérios que um protestante ou um umbandista, por exemplo. Aqui não entra juízo de valor, se melhor ou pior, mas os princípios que o regem. Nesse sentido, pessoas com uma identidade religiosa clara podem, por exemplo, num debate sobre o aborto ou casamento de homossexuais, se posicionar de maneira, inclusive, contraditória, ou podem defender a mesma posição, mas fundamentadas numa compreensão diferente sobre a liberdade e o direito de decidir. (Lopes, 2005, p. I)

Como se vê, a concepção da representante da Secretaria Estadual de Educação é muito diferente da que vigora entre os profissionais ouvidos neste trabalho. É uma concepção afirmativa da confessionalidade, dificilmente conciliável com a prescrição legal do não proselitismo. Não havendo orientação das igrejas católica e evangélicas, no Rio de Janeiro, para a prática da forma interconfessional, mas sendo esta a forma considerada possível pelos professores de ER e demais profissionais que apóiam o ER nas escolas, as soluções têm sido encontradas pelos próprios professores, em decorrência de suas visões particulares do que seja esse trabalho interconfessional e das condições objetivas que encontram para executá-lo. Por isso não se percebeu regularidade no tipo de trabalho realizado. Cada professor de ER tem imprimido sua versão particular daquilo que considera ser necessário ou importante para os alunos, a título de ensino religioso. Alguns entendem a forma interconfessional do ER como história das religiões, outros como trabalho com direitos, deveres e cidadania, outros ainda como fortalecimento de valores morais.

Vieram me perguntar se era uma antiga Moral e Cívica ou o antigo OSPB, que nós tínhamos antigamente, ou Sociologia, mas eu acho que não é nada disso, eu acho que é uma mistura disso tudo, mas nunca deixando de passar o lado religioso também. (Professor 9 de ER)

...acho que a proposta de trabalhar por credo não seria boa porque vai entrar na divergência religiosa, vai dividir em grupos; acho que eles têm que aprender é na 
O mal-estar do ensino religioso...

diversidade; por credo seria um problema muito mais complicado do que a gente já vê aí fora, na comunidade. Acho que o título da disciplina deveria ser trocado por antropologia filosófica, mas o concurso foi por credo. (Professor 7 de ER)

Entretanto, os depoimentos e observações também mostraram que, mesmo afirmando e defendendo o caráter interconfessional de seu trabalho, os dogmas elementares do credo de cada professor tendem a predominar, mesmo que de forma não intencional ou explícita, encobertos pelo sentido de valores universais ou ecumênicos.

Em meio a uma grande confusão de conceitos e objetivos, de intenções e resultados, a tese da Coordenadora de ER da Secretaria de Educação, de certa forma, confirmou-se:

Aí, eu trabalhei, fiz um dia de perdão, trabalhei conteúdo, dei conteúdo teológico, de onde veio o termo Bíblia, de onde vem essa escrita. Dei conteúdo mesmo, porque é nível médio, e eu gosto mais desse trabalho com conteúdo. De onde se tira esse conceito de fé? De onde se tira esse conceito de religare, religião [...] aí eu fui trabalhando o perdão, trabalho também com dinâmicas, músicas, trabalho com muitas músicas. Na última festa eu dei essa Oração da Família, do Padre Zezinho... (Professor 2 de ER)

Eu digo sempre pra professora de ER: trabalha com todo mundo, não faz muita diferença para a católica! Puxa um pouquinho pro ecumênico! Mas eu sei que ela [a professora de ER] tem sempre a tendência, e acaba escapulindo para a católica, é natural! (Diretora de escola)

Em razão das contradições da própria experiência, fica evidente para os professores de ER a incompatibilidade entre ensino religioso confessional e a pretensa ausência de proselitismo:

Nós fizemos o concurso confessional mas, na nossa atuação, não podemos pregar, e nem trazer adeptos para aquilo que a gente crê. Então para mim eu acho que isso, daqui a algum tempo, vai haver uma reforma na legislação e vai funcionar como está funcionando hoje. A lei prevê outra coisa, na realidade a gente 
funciona de maneira diferente, mas eu acho que por conta da força da atuação, do fazer, da realidade, essa lei vai ser modificada, porque é o correto, não tem cabimento. A confessionalidade seria quase um proselitismo porque você teria que, vamos dizer assim, você teria que dizer para o outro aquilo que você acredita dentro da sua fé religiosa, dogmática. Vou pegar como exemplo a mim, que sou evangélica e batista. A minha denominação é batista, então eu não sou da assembléia de Deus, da Maranata; cada denominação, mesmo sendo do mesmo credo, ela tem dogmas, doutrinas, que diferem umas das outras, então você já pensou que miscelânea na cabeça das crianças, do adolescente e dos jovens? Então você não pode entrar nisso e o professor que entra nisso, eu acho que ele é despreparado e ele está correndo um grande risco, porque o aluno, por menos instrução ou cultura ou antenado, ele percebe isso, eu acho que o carisma, eu acho que a palavra certa seria isso, o carisma que eu consegui com eles é porque eu respeito eles enquanto seres humanos. (Professor I de ER)

Eu estava conversando com a professora [outra professora de ER], encontrei-a na reunião e ela falou que está sendo muito difícil trabalhar com os alunos sobre isso, porque uns aceitam outros não e então uns falam que são evangélicos, outros protestantes e nós não podemos seguir nenhuma linha de raciocínio católico, tem que seguir uma linha de raciocínio religioso, trabalhar com religiosidade, o que é diferente. (Professor 9 de ER)

\section{OS PROFESSORES DE ER: UMA TIPOLOGIA}

Nas 14 escolas da amostra registrou-se a existência de 27 professores de ER ativos, ocupando 38 cargos, os quais se distribuíam em 28 matrículas e dez "lotações prioritárias". Seguindo a prática comum na rede estadual do Rio de Janeiro, de cumprimento, pelos professores efetivos, de carga horária suplementar (gratificação por lotação prioritária - GLP5), foram encontrados, entre os 38 cargos de professor de ER, dez, dessa natureza, isto é, 26\%. Extrapolando

5. A GLP pode ser cumprida na mesma escola em que o professor está lotado com sua(s) matrícula(s) ou em outra unidade escolar, de acordo com a necessidade. Há professores com duas matrículas e uma GLP, ou ainda com uma matrícula e duas GLPs, o que representa de 48 a 60 horas-aula semanais. 
O mal-estar do ensino religioso...

QUADRO 3

TOTAL DE PROFESSORES/MATRÍCULA POR ESCOLA, DISTRIBUIÇÃO POR CREDO DO TOTAL DE PROFESSORES E CREDO DOS PROFESSORES DE ER ENTREVISTADOS

\begin{tabular}{|c|c|c|c|c|c|}
\hline ESCOLA & $\begin{array}{l}\text { Total de profs. } \\
\text { (inclusive GLP)* }\end{array}$ & $\begin{array}{c}\text { professores } \\
\text { católicos }\end{array}$ & $\begin{array}{l}\text { professores } \\
\text { evangélicos }\end{array}$ & $\begin{array}{c}\text { professores } \\
\text { espíritas }\end{array}$ & $\begin{array}{l}\text { Profs. de ER } \\
\text { entrevistados }\end{array}$ \\
\hline $\begin{array}{l}\text { Escola I } \\
\text { Nilópolis }\end{array}$ & 8 & 4 & 4 & & $\begin{array}{c}\text { | } \\
\text { evangélico }\end{array}$ \\
\hline $\begin{array}{l}\text { Escola } 2 \\
\text { Nilópolis }\end{array}$ & 4 & 4 & & & $\begin{array}{c}2 \\
\text { católicos }\end{array}$ \\
\hline $\begin{array}{l}\text { Escola } 3 \\
\text { N.Iguaçu }\end{array}$ & I & I & & & $\begin{array}{c}\text { I } \\
\text { católico }\end{array}$ \\
\hline $\begin{array}{l}\text { Escola } 4 \\
\text { N.Iguaçu }\end{array}$ & 4 & 4 & & & $\begin{array}{c}\text { I } \\
\text { católico }\end{array}$ \\
\hline $\begin{array}{l}\text { Escola } 5 \\
\text { Japeri }\end{array}$ & I & & I & & $\begin{array}{c}\text { I } \\
\text { evangélico }\end{array}$ \\
\hline $\begin{array}{l}\text { Escola } 6 \\
\text { N.Iguaçu }\end{array}$ & I & I & & & $\begin{array}{c}\text { I } \\
\text { católico }\end{array}$ \\
\hline $\begin{array}{l}\text { Escola } 7 \\
\text { D.Caxias }\end{array}$ & 3 & 2 & I & & $\begin{array}{c} \\
\text { católico }\end{array}$ \\
\hline $\begin{array}{l}\text { Escola } 8 \\
\text { D.Caxias }\end{array}$ & 2 & 2 & & & $\begin{array}{c}\text { I } \\
\text { católico }\end{array}$ \\
\hline $\begin{array}{l}\text { Escola } 9 \\
\text { Rio de Janeiro }\end{array}$ & 3 & & I & 2 & $\begin{array}{c}\text { I } \\
\text { espírita }\end{array}$ \\
\hline $\begin{array}{l}\text { Escola } 10 \\
\text { Rio de Janeiro }\end{array}$ & । & I & & & $\begin{array}{c} \\
\text { católico }\end{array}$ \\
\hline $\begin{array}{l}\text { Escola I I } \\
\text { Rio de Janeiro }\end{array}$ & I & I & & & $\begin{array}{c}\text { I } \\
\text { católico }\end{array}$ \\
\hline $\begin{array}{l}\text { Escola } 12 \\
\text { Rio de Janeiro }\end{array}$ & 1 & I & & & $\begin{array}{c}\text { । } \\
\text { católico }\end{array}$ \\
\hline $\begin{array}{l}\text { Escola } 13 \\
\text { Rio de Janeiro }\end{array}$ & 4 & 3 & I & & $\begin{array}{c}2 \\
\text { católico/evangélico }\end{array}$ \\
\hline $\begin{array}{l}\text { Escola I4 } \\
\text { Rio de Janeiro }\end{array}$ & 4 & I & 3 & & $\begin{array}{c}\text { | } \\
\text { evangélico }\end{array}$ \\
\hline TOTAL & 38 & 25 & 11 & 2 & 16 \\
\hline
\end{tabular}

Fonte: Amostra de 14 escolas da rede estadual do Rio de Janeiro 
desse percentual para o conjunto dos 500 professores de ER contratados, obtém-se 630 cargos. Acrescentando-se a esses os cerca de 250 professores de outras disciplinas, com desvio de função, que já ministravam ensino religioso antes da nova lei e continuaram a fazê-lo, chega-se a 880 professores. Considerando ainda a existência de contratos temporários (extra- quadros) feitos a cada semestre, pode-se elevar a estimativa para cerca de mil professores. Essa quantidade, entretanto, fica muito aquém da que seria necessária para o cumprimento da "oferta obrigatória" da disciplina para todas as turmas da educação básica, de acordo com a Lei n.3.459.

As 14 escolas da amostra têm, em média, 2,7 cargos de professor de ER sendo que a quantidade variou de um a oito cargos por escola. As religiões encontradas foram a católica, a evangélica e a espírita, com respectivamente 25, II e dois cargos.

Como já dito, sete dos 16 professores de ER entrevistados já possuíam vínculo com a rede e, tendo feito o concurso para a disciplina ER, passaram a ter duas matrículas em duas disciplinas diferentes.

No quadro 3 confirma-se o predomínio numérico dos professores católicos. Em apenas duas das 14 escolas estudadas não havia pelo menos um professor católico, enquanto em oito delas, não havia professor evangélico e em apenas uma, havia um professor espírita (com a carga horária dobrada).

No conjunto dos profissionais docentes, a predominância católica não é apenas numérica. $\bigcirc$ cotejamento, por exemplo, entre religião e tipo de cargo ocupado na escola revela tendências interessantes. Entre os 20 profissionais das equipes de direção que responderam o questionário foram encontrados 14 católicos, um evangélico, um espírita e quatro sem religião, ou seja, 70\% de católicos. Já entre os 60 professores das disciplinas convencionais que responderam ao questionário, encontraram-se 29 católicos, 18 evangélicos, cinco espíritas, um professor de religião afro-brasileira e sete professores sem religião, ou seja $49 \%$ de católicos. A maior presença de professores católicos ocupando cargos de direção na amostra se deve à distribuição das religiões nos agrupamentos socioeconômicos, confirmando o dado estatístico de que a religião católica predomina nos extratos econômica e culturalmente dominantes da sociedade brasileira (Jacob et al., 2003).

O status do professor de ER nas escolas depende, em grande parte, da posição da direção e do corpo docente em relação à presença dessa matéria 
O mal-estar do ensino religioso...

na escola. De outra parte, depende das características individuais dos professores de ER e do espaço que conquistam ou obtêm nas escolas, variando bastante suas formas de inserção e atuação. Para melhor descrever e compreender essas formas de atuação, foi elaborada uma tipologia com base nos 16 professores entrevistados.

\section{Perfil I: sem prestígio}

Esse perfil se estabelece quando a direção e o grupo mais influente de professores discordam das aulas de ER ou, simplesmente, as ignoram. $\bigcirc$ professor não recebe apoio da direção, não é prestigiado pelos pais ou nos momentos importantes da vida escolar. Quando, além disso, se trata de um professor sem carisma, ou sem capacidade para elaborar uma aula de religião palatável ao clima escolar, cria-se uma situação muito desfavorável a ele, que é ignorado pelos outros professores e ridicularizado pelos alunos. Suas aulas são esvaziadas ou há muita indisciplina em sala.

\section{Perfil 2: líder pedagógico}

Trata-se de um tipo de professor de ER que já traz consigo grande experiência no magistério. Torna-se respeitado pelos demais colegas e imprime o tom em todas as atividades interdisciplinares, complementares ou extracurriculares planejadas pela escola. Quando apoiado pela direção, se torna um coordenador informal dos projetos e atividades do coletivo escolar. Imprime a essas atividades, ainda que de maneira sutil, a marca do ER, mas garantindo a incorporação de todos os credos. Observou-se em quatro escolas a elaboração de projetos ou planejamento de atividades coletivas com base na Campanha da Fraternidade da CNBB.

\section{Perfil 3: capelão}

São professores fortemente engajados na militância religiosa e que se caracterizam por valorizar a liturgia, os rituais e a simbologia religiosa. Promovem encontros de oração, cantos, momentos coletivos de "reflexão" entre professores e alunos. Quando apoiados pela direção têm posição de destaque 
em todos os rituais da escola. Buscam interferir nas crises provocadas por problemas disciplinares de alunos ou desentendimentos entre professores, fazendo uso direto de práticas religiosas com vistas a desanuviar tensões e reaproximar indivíduos. Promovem orações nas solenidades, coordenam grupos de oração sistemáticos ou emergenciais com professores e alunos.

\section{Perfil 4: amigo dos alunos}

São professores jovens, que em geral estão vivendo a primeira experiência docente. Superam a insegurança aproximando-se pessoalmente dos alunos e praticando a camaradagem. Tornam-se um misto de confidentes e conselheiros. Nas aulas abordam em geral temas ousados, como sexo e drogas. Utilizam gírias e linguajar informal e semelhante ao utilizado pelos alunos. No início de carreira, tiveram com o ER uma chance de introdução no mercado de trabalho. Em dois casos, explicitaram sua pouca convicção sobre o ER escolar e sublinharam sua relação profissional pragmática com a matéria.

\section{Perfil 5: orientador educacional}

É um tipo de professor experiente, com pendor e disposição para a orientação educacional. Prefere tratar das questões individuais a interferir no projeto da escola. Assume a condução dos casos de alunos-problema. Conhece as condições de vida a que estão submetidos os alunos e tem sempre inúmeros episódios, alguns trágicos, a relatar. Ouve e aconselha esses alunos e, quando necessário e possível, faz contato com as famílias. Quando não há orientador na escola, assume essa função. Quando há orientador educacional, entra em concorrência com ele. Um caso de conflito aberto entre esses dois profissionais foi observado.

Os cinco perfis foram elaborados com base não apenas nas informações prestadas pelos próprios professores de ER, mas também no que pudemos ouvir das equipes de direção e demais professores da escola. Presenciamos inúmeras situações e atividades que também forneceram elementos para essa elaboração. Em alguns casos, mais de uma tipologia aplica-se a um mesmo professor, uma vez que os perfis estabelecidos não correspondem a descrições precisas dos indivíduos que entrevistamos, mas a construções aproximativas ela- 
O mal-estar do ensino religioso...

boradas a partir da percepção de tendências e prioridades das ações de cada um e do conjunto estudado.

\section{PLURALIDADE DE CONFISSÕES E INTOLERÂNCIA RELIGIOSA}

O ensino religioso nas escolas do Rio tem-se mantido inteiramente no âmbito das religiões católica e protestante. A inexistência de estruturas de poder burocratizadas entre as religiões afro-brasileiras e o não apoio das principais associações espíritas ao ensino religioso (Giumbelli, Carneiro, 2004) nas escolas levou a um reduzidíssimo número de professores dessas confissões. Entre as escolas localizadas na capital do Rio de Janeiro, o único professor de religião afro-brasileira está de licença e o único professor espírita kardecista, credenciado por um centro espírita dissidente, foi entrevistado neste estudo (aparece no quadro 3 com dupla matrícula). Esse professor defendeu o interconfessionalismo e reafirmou sua formação cristã. As religiões judaica, muçulmana e orientais não têm representantes entre os professores.

Percebe-se, nas escolas visitadas, um consenso implícito que faz com que, quando se fala em religião, todos remetam exclusivamente às religiões cristãs. O silêncio sobre as religiões afro-brasileiras foi poucas vezes quebrado e sempre pela iniciativa dos pesquisadores. Essas tentativas de quebra de silêncio desencadeavam depoimentos em tom baixo de voz, olhares para os lados, atitudes de constrangimento. Dos 96 profissionais ouvidos, apenas uma professora, de Língua Portuguesa, adepta do candomblé, se referiu espontaneamente, e positivamente, a essa religião.

Um julgamento superficial das informações obtidas neste estudo nos levaria a sugerir que a população que freqüenta essas escolas, e que inclui um expressivo contingente de alunos negros, está muito distante das religiões afrobrasileiras. Ainda que as religiões de origem africana estejam vivendo um momento de retração (Pierucci, 2004), o silêncio a respeito parece demasiado. No momento em que o país inclui no currículo de todas as escolas a cultura afro-brasileira ${ }^{6}$, o fato de os adeptos dessas religiões nas escolas não se mani-

6. A Lei Federal n. 10.639/2003 estabelece a obrigatoriedade do ensino de História e Cultura Afro-Brasileiras e Africanas, e o Parecer CNE/CP 3/2004 define suas Diretrizes Curriculares Nacionais. 
festarem sobre o assunto é um problema preocupante a ser compreendido e considerado, e um sinal do preconceito e de um possível crescimento da intolerância religiosa.

A gente estuda as religiões, o que cada uma religião prega, a história das religiões - os umbandistas ficam constrangidos de falar sobre a sua religião, mas como a aula é bem neutra eles falam, ou melhor, um ou outro fala - mas os umbandistas, eles são difíceis, são um grupo com dificuldade de se expressar; os católicos e os evangélicos falam bem mais. (Professor 7 de ER)

Pequenos mas reveladores, os detalhes foram captados em diversos discursos semelhantes, emitidos como resposta à pergunta sobre a presença das religiões afrodescentes em sala de aula: "já me deparei com alguns. Pessoas com uma formação muito boa, por incrível que pareça". (Professor 5 de ER)

No conjunto de 80 professores de disciplinas diversas e membros das equipes de direção ouvidos, 54 declararam que deve haver ER nas escolas públicas e 25 declararam que não deve haver. Foi grande a coincidência entre professores espíritas ou sem religião e a posição contrária ao ER na escola, embora alguns militantes religiosos também tenham se manifestado contrariamente.

A posição contrária ou favorável nem sempre está diretamente relacionada ao ativismo religioso dos profissionais. Encontraram-se em três escolas diferentes, diretoras que, embora ativistas católicas, posicionaram-se contra o ER; uma delas, da corrente carismática, argumentou com firmeza que "escola não é lugar de religião". Foram identificados ainda oito professores, de disciplinas diversas, fortemente engajados institucionalmente em alguma religião, que se mostraram descrentes quanto à possibilidade de ser feito um trabalho religioso de qualidade na escola. Portanto, o engajamento pessoal dos indivíduos em uma religião nem sempre determinou um posicionamento favorável ao ER.

Ainda que o formulário padronizado de matrícula contemple o quesito "religião do aluno". a maioria das escolas deixou-o em branco, no início do ano de 2005, embora a disciplina ER já estivesse sendo oferecida. Provavelmente essa omissão não foi casual e se deveu ao fato de as direções haverem perce- 
O mal-estar do ensino religioso...

bido a impossibilidade prática de um trabalho confessional de ER na escola ou, ainda, ao conhecimento de que a constituição estadual impede a exigência desse tipo de declaração.

Segundo os depoimentos dos professores, principalmente das demais disciplinas, mas também dos próprios professores de ER e das direções das escolas, uma parte considerável dos alunos rejeita as aulas de ER. Ao contrário do que se possa imaginar, os alunos que professam uma religião e nela se aplicam freqüentemente consideram desnecessárias as aulas na escola, pois já realizam sua vida religiosa nos respectivos templos. Ainda segundo os professores, quanto mais avançada a faixa etária, mais numerosos são os que consideram as aulas desnecessárias e prefeririam usar esse tempo de outra forma.

Como as aulas têm tido caráter pretensamente interconfessional, e os alunos de vários credos as assistem em conjunto, muito freqüentemente há questionamentos entre colegas ou mesmo ao professor de ER, em razão de diferenças religiosas.

...teve uma menina que é espírita, praticante, e eu tenho muito carinho por todos eles, não entro em credo, respeito, respeito mesmo porque é isso que está dentro de mim. Aí eu entrei na sala e ela disse assim "professora, a senhora é professora de religião, né?" Aí eu disse assim: "sou sim, meu amor". E ela disse assim: "meu amor não, porque eu não gosto de intimidades". E eu disse: "pois não querida o que você quer saber?" e ela, "eu queria saber qual é a sua religião?" Ela estava sendo dura e confrontando e aí eu disse: sou evangélica por quê? "Porque eu sou espírita". Aí eu falei e daí? "Eu não sou obrigada assistir a sua aula". E eu disse "não é mesmo, mas a ordem da direção eu não posso descumprir..." (Professor I de ER)

Os alunos preferem usar o tempo da aula de religião para o estudo em grupo. Aí aceitei a decisão da turma que passou a não ter as aulas de ensino religioso. Disse para a professora de ER: "não liga, não! Porque é um bando de evangélicos! Não adianta! Eles não querem, é melhor deixar pra lá!” Mas eu sei que é a professora de Física [ex-diretora da escola], que acha um absurdo o aluno ter apenas duas aulas de Física e desperdice um tempo com Religião, é ela que incentiva o aluno a não participar porque diz: "como ter dois tempos de Física e um de Religião"? Ela incentiva o aluno a resistir. (Diretora adjunta de escola) 
Existem alguns professores que jogam indiretas; falam que é a religião do governo que está na escola, principalmente o professor de Química e o de Biologia. Ano passado trabalhei questões do criacionismo, dizendo que é um estudo científico, porque acredito nisso. Deu muita confusão porque o professor de Biologia estava também trabalhando o evolucionismo. $\bigcirc$ aluno ouvia um professor falando de uma concepção e o outro defendendo uma outra posição; o aluno fazia os dois trabalhos ao mesmo tempo. Resolvi então abolir o trabalho a respeito do criacionismo. (Professor 4 de ER)

Em outras escolas da nossa região metropolitana o ER está pegando fogo. Isto é o que presencio nas reuniões que temos, pois as discussões e os conflitos são muito grandes. É briga o tempo todo! Não existe uma orientação da SEE ou da Coordenadoria. $O$ professor tem que fazer o que as diretoras querem e elas não apóiam o trabalho de ER. Existem diretoras que: não dão o diário de classe para o professor de ER; deixam o professor de ER em um canto da escola sem fazer nada, desviam o professor de ER da disciplina para fazer outras coisas para a escola; oferecem outras disciplinas para o professor de ER trabalhar; É por isso que o professor de ER está perdido e não sabe o que vai acontecer diante dessa situação. A gente sabe que esse problema é um risco porque coloca uma interrogação na funcionalidade do ER; a dificuldade maior é que a gente está em estágio probatório que é de três anos, e nós ainda estamos no $2^{\circ}$ ano de trabaIho. (Professor 4 de ER)

Eu dei uma aula na outra escola, onde ensino História, falando sobre Idade Média, sobre o poder da Igreja Católica, a turma me adorava. Aí eu fui discutir um texto com eles sobre uma música do Gilberto Gil: "Olha lá, vai passando a procissão, se arrastando feito cobra pelo chão (...) Jesus se esqueceu de dizer que na Terra a gente tem que arrumar um jeitinho para viver". Olha, eles não suportaram, não chegou nem no final. Eles não permitiram, acharam aquilo execrável, principalmente os evangélicos. É isso, é que eles achavam que era uma afronta ao credo, entende? E na época, ele [Gilberto Gil] já era Ministro da Cultura. (Professor 3 de ER)

Sem exceção, os professores de ER entrevistados afirmaram ter vivenciado questionamentos de ordem doutrinária, vindos de alunos. A grande 
O mal-estar do ensino religioso...

maioria dos profissionais, isto é, 85 deles, no conjunto dos 96 que participaram da pesquisa, demonstrou preocupação com a possibilidade de existirem conflitos religiosos nas escolas. A presença do ER nas escolas, ao invés de funcionar, tal como proclamado por alguns, como espaço para a ampliação da compreensão e da tolerância religiosa, parece atuar na direção do acirramento entre as diferentes posições, podendo ser interpretada - a própria lei e suas conseqüências - como elemento intrínseco e ativo do processo de acirramento das disputas entre as denominações evangélicas, em franca expansão, e a reação a elas por parte da Igreja Católica.

\section{REFLEXÕES E CONCLUSÕES}

O tipo de ER que se encontrou nas escolas estudadas durante os anos de 2005 e 2006 não se caracteriza pela pluralidade religiosa tal como defendido durante o processo de tramitação da Lei n.3.459. Na prática o ER nas escolas do Rio de Janeiro é obrigatório para a $5^{\mathrm{a}}$ a $8^{\mathrm{a}}$ séries (exceto nos casos de pedido explícito dos pais), não é confessional e não é plural. Os três princípios da lei aprovada estão sendo descumpridos por total impossibilidade prática de execução. Especificamente no que diz respeito ao caráter confessional, o descumprimento da lei é reforçado pela concepção predominante entre os profissionais docentes de que o ER deve ser interconfessional e situado no campo cristão.

Ainda que a maioria dos profissionais esteja encarando o ER como "tábua de salvação" para os problemas que as escolas públicas enfrentam com seu alunado, a introdução das aulas de religião não está ocorrendo sem grande desconfiança e muitas dúvidas, mesmo por parte daqueles que, numa primeira aproximação, se dizem favoráveis a elas.

Quando solicitados a opinarem sobre como deveria ser o ER na escola, a maioria dos professores descreve formas muito genéricas de trabalho pedagógico com "valores", "amor", "direitos e deveres", "ética", "respeito", "solidariedade", enfim, um conjunto de noções que não dependem e nem são exclusivas da dimensão religiosa.

Se a entrada do ER nas escolas, com o novo formato legal, encontrou resistências por parte da comunidade escolar, tais resistências não chegaram a se converter em ações coletivas, e o decorrer do tempo parece contribuir para uma gradativa acomodação. Ficou claro, no estudo, que o espírito laico, que 
já teve uma marca significativa na escola brasileira e fluminense, nela se enfraquece. É recorrente a idéia de que "o ER pode ser bom" ou que "mal não fará".

Não se pode deixar de ver, entretanto, a presença da disputa. Muitas vezes ela se faz de modo surdo, seja pela recusa dos alunos, seja pelo desprestígio dos professores de ER. A grande preocupação com o conflito religioso, também, é indício da presença da cultura secular, ainda que apenas oito professores tenham elaborado discursos claros e inequívocos em defesa da escola pública laica ou contra a presença do ER como disciplina escolar.

Da mesma forma, a recusa dos professores de ER a assumirem a versão confessional desse ensino pode ser vista como indicadora da existência de um consenso social em torno da idéia de que religião é opção pessoal; pode indicar a presença de escrúpulos quanto à ação proselitista no espaço escolar. Percebeu-se que, na ausência de orientações para um trabalho interconfessional, muitos professores de ER - mesmo quando demonstram estar genuinamente convencidos de que fazem um trabalho interconfessional - trabalham, de modo pouco explícito, com seu próprio credo. Entretanto, esses profissionais não parecem convictos de que estão ali para formar alunos para uma religião específica, mas sim para dar uma contribuição para a formação geral.

O recorrente desprendimento dos professores de ER entrevistados, ao afirmarem sua disposição para o trabalho interconfessional, pode ser visto como indício da natureza individualista do fenômeno religioso contemporâneo, que se caracteriza pela fluidez das adesões.

No debate travado na área da Sociologia das Religiões, contrapondo a tese de que o mundo está irreversivelmente secularizado à de que se está vivendo uma dessecularização impulsionada pela crise da moral e da racionalidade técnico-científica, Pierucci (1997), alinhado com a primeira, vê na pluralização das religiões a criação de uma espécie de mercado em que impera uma atitude pragmática, egoística e incompatível com o papel tradicional moralizador da religião. Pode-se imaginar que, na sua fragmentação, a religião estaria se aproximando da esfera da auto-ajuda, do consumo e da terapêutica individual, sem a força coletiva que já teve. A proliferação de confissões com caráter mercadológico e a disputa entre elas por adeptos seriam indícios do declínio da religião como ideal coletivo, investido de uma autoridade que faz com que os sujeitos particulares que a ele aderem representem-no como força moral que os domina e sustenta. Nessa visão, a evidente explosão de reli- 
O mal-estar do ensino religioso...

giosidade no mundo contemporâneo seria uma espécie de "canto do cisne" de um mundo já radicalmente desencantado.

Os professores de ER, já por demais imersos na cultura secular, não parecem convencidos de que o seu credo pessoal poderá servir indiscriminadamente a qualquer outro indivíduo. Mobilizam-se pela idéia de que o que importa é ter uma religião, qualquer que seja. Demonstram um tipo de adesão ao ensino religioso, de certa forma, já dessacralizada, imbuída do sentimento de que os dogmas são "uma questão pessoal". O controle social que imaginam poder obter por meio de um espírito religioso qualquer é, assim, ilusório, pois não há consenso sobre a origem da força moral coletiva que poderá a todos orientar, ao menos se se pensar nos moldes do fenômeno religioso tradicional, descrito pela sociologia de Émile Durkheim.

A presença de arraigadas formas culturais secularizadas acaba impondo novos sentidos ao ER, muitas vezes contrários aos pretendidos no projeto pedagógico vitorioso. A forma pela qual tem sido socialmente interpretado e praticado o ER nas escolas públicas do Rio de Janeiro pode ser vista como indicadora das contradições e particularidades do processo contemporâneo de dessecularização da cultura, ainda a ser mais bem compreendido e caracterizado.

\section{REFERÊNCIAS BIBLIOGRÁFICAS}

GIUMBELLI, E.; CARNEIRO, S. de S. Ensino religioso no Estado do Rio de Janeiro: registros e controvérsias. Rio de Janeiro: Iser, 2004.

JACOB, C. R. et al. Atlas da filiação religiosa e indicadores sociais no Brasil. São Paulo: Loyola, 2003.

LOPES, V. G. Fundamentos epistemológicos do ensino religioso confessional e plural. Rio de Janeiro, 2005. [Apres. ao I Seminário de Ensino Religioso do Leste I, Rio de Janeiro: CNBB, SEE, Uerj, dez. 2005]

PIERUCCI, A. F. "Bye, bye, Brasil", o declínio das religiões tradicionais no censo 2000. Estudos Avançados, São Paulo, v. I8, n.52, p. 17-28, set./dez. 2004. (Dossiê: Religiões no Brasil)

. Reencantamento e dessecularização: a propósito do auto-engano em sociologia da religião. Novos Estudos, São Paulo, n.49, p.99-1 17, nov. 1997. 
SANTOS, J. V. T. dos. Violências e dilemas do controle social nas sociedades da "modernidade tardia”. São Paulo em Perspectiva, São Paulo, v.8, n. I, p.3-12, jan./mar. 2004.

Recebido em: janeiro 2007

Aprovado para publicação em: janeiro 2007 